\title{
ВПЛИВ ОСВІТНІХ РЕФОРМ НА РОЗВИТОК ШКІЛЬНОГО ПІДРУЧНИКОТВОРЕННЯ 3 ПРИРОДНИЧИХ ДИСЦИПЛІН В УКРАЇНІ ДРУГОЇ ПОЯОВИНИ ХХ СТОЛІТТЯ
}

\begin{abstract}
Стаття присвячена розгляду історико-педагогічного аспекту проблеми підручникотворення, зокрема вихиву освітніх реформ на його розвиток в Україні другої половини ХХ століття. Автором обьрунтовано актуальність проблеми, уточнено контент ключових понять «підручникотворення», «теорія підручника», проаналізовано переваги ітруднощі, сильні і слабкі сторони у створенні шккільного підручника з природничих дисциилін у тогочасній освіті, простежено вектори і динахіку змін цุвого процесу в окреслених хронологічних межах.

Студіювання наукових праць з історії педагогіки дало змогу з'ясувати, як науковотехнічний прогрес, пануюча на різних етапах розвитку суспільства влада, суспільно-політичні та соціально-економічні умови викликали проблеми $і$ певні труднощі у изьому напрямі діяльності освітньої галузі.

Оскільки вимоги до икільного підручника в усі часи висувалися високі, процес його створення потребував особливих підходів, вдосконалення якості його розроблення і випуску, а також модернізації структури, оновлення змістового наповнення. Зроблено спробу простежити характер таких змін у період від початку 50-x років минулого століття до початку наступного.

Сучасні вилоги до розроблення шкільної навчальної книги значно ускладнилися. Водночас класичні канони, прописані ще за часів Я.А. Коменського, залишаються актуальними і сьогодні. Відповідно до зазначеного, на основі ретроспективного аналізу процесів у вказаний період, визначено механізми підручникотворення, труднощі та характер змін в алгоритмі розроблення, вибору, виконання шкільної книги, врахування ї специфіки для вивчення природничих дисцичплін.

На основі аналізу науково-педагогічної літератури виявлено основні здобутки щзоо вирішення проблем створення шкільного підручника з природничих дисииплін, можливості екстраполяції конструктивного досвіду минулого в сучасну теорію $і$ практику освіти, щцо періодично зазнає суттевих трансформацій.

Ключові слова: освітня реформа; підручникотворення; теорія підручника; природнича освіта; предмети природничого цุиклу.
\end{abstract}

Постановка проблеми. Сучасна освіта перебуває на порозі серйозного випробування, коли реформа, пов'язана з розбудовою Нової української школи, досягла етапу переходу до середньої ланки шкільної освіти. Цей перехід детермінуе перегляд застарілої, на думку певного кола науковців, предметної форми навчання, її заміну на популярнішу сьогодні - інтегровану, що має забезпечити сформованість у здобувачів освіти цілісних наукових уявлень про навколишній світ. Затвердження Державного стандарту базової середньої освіти, що почне діяти з 1 вересня 2022 року для учнів, які навчаються за програмами дванадцятирічної повної загальної середньої освіти, спричинило суттеві зміни у змісті шкільної освіти. Відтак зростає значення підручника, що розглядається як засіб освітньої діяльності для вчителя й учня з точки зору його технологічності і процесуальності.

*(C) Примакова В. В.

U3 203 
Аналіз досліджень. На нинішньому етапі розвитку освіти в Україні не згасає увага теоретиків і практиків до питань підручникотворення. Теорію шкільного підручника для масових шкіл розробили й обгрунтували науковці Д. Д. Зуєв, Н. О. Менчинська, Є. Й. Перовський. Історію підручникотворення на території України в XX столітті вивчали Л. Б. Березівська, Я. П. Кодлюк, В.В.Кузьменко та ін. Різною мірою питань розвитку шкільного підручника з природничих дисциплін торкалися у своїх наукових працях Н. І. Бібік, К. Ж. Гуз, В. Р. Ільченко, А. В. Степанюк та ін. Дослідження проблем сучасного підручника мають широкий діапазон: від розроблення його концепції, що має відповідати чинним освітнім стандартам, специфіки його практичного використання в умовах реформування галузі до ретроспективного аналізу трансформації шкільного підручника та екстраполяції найціннішого досвіду минулого в сучасність.

Не зважаючи на потужний масив напрацювань із зазначених питань у педагогічній теорії, наукові пошуки в історичній площині мають продовжуватися. Оскільки одним із векторів нинішніх змін $є$ трансформація змісту шкільної освіти, то важдивості набуває проблема забезпечення оновленого освітнього процесу сучасним, змістовним, оригінальним, дієвим підручником для вивчення предметів і дисципдін, зокрема природничого циклу. Цінність досвіду минулого у вирішенні цієї проблеми актуалізує проблеми створення сучасного шкільного підручника та орієнтує на пошуки здобутків уцій царині в період, коли відбувалися суттєві трансформації змісту, структури шкільного підручника, вимог до його розроблення і публікації.

Метою статті є виявлення основних здобутків у вирішенні проблем створення шкільного підручника з вивчення природничих дисциплін, впливу на цей процес освітніх реформ і нововведень XX стодіття.

Відповідно, завданнями розвідки визначаємо такі: розглянути історикопедагогічний аспект проблеми, простежити вплив освітніх реформ на розвиток підручникотворення в Україні другої половини XX століття; схарактеризувати позитивні й негативні чинники такого впливу та виявити можливості екстраполяції конструктивного досвіду минулого в сучасну теорію і практику трансформованої освіти.

Виклад основного матеріалу. На різних історичних етапах висувадися високі вимоги до якості «книги для навчання», що вирізнялися за різними ознаками. Яном Амосом Коменським, якого визнано засновником теорії навчальної книги («дидахографії)), було висунуто низку вимог до розроблення та застосування підручника на уроці. Згідно його висновків, підручник мав бути: «невеликим за обсягом, стислим і змістовним; написаним зрозуміло і доступно; таким, що містить весь необхідний матеріал; добре ілюстрованим, чітко структурованим і прозорим; виклад матеріалу має бути грунтовно продуманим, написаним математичним методом (тобто доказово), у формі діалогу» [3, с. 36].

Видатний педагог переконував сучасників у необхідності створення для вихованців спеціальних книг 3 оригінальним відредагованим змістом і 1658 року сам створив перший ілюстрований підручник для найменших учнів «Видимий світ у малюнках», у змісті якого практично реалізував принцип наочного навчання [там само, с. 37]. Ці загальні вимоги, відображені в одній із перших шкільних книг про природу, є актуальними і нині. Водночас сьогодення потребує пошуку такої моделі підручника, який увиразнить його відповідно до оновлених вимог у стрімкому міндивому світі та зробить продуктивнішим здобуття освіти учнем сучасної школи.

Автор грунтовного дослідження проблем вітчизняного підручникотворення у галузі початкової освіти України періоду 1960-2000 років Я.П. Кодлюк на основі ретроспективного аналізу виокремила два основних його етапи: розвиток підручникотворення в початковій освіті у 60-80-х роках XX століття; підручникове забезпечення початкової школи в умовах державної незалежності України [2]. 
Значну увагу проблемам шкільного підручника, його створення, змісту та залежності зазначеного від освітніх реформ у XX столітті приділив В. В. Кузьменко. Зокрема вчений, досліджуючи історичний аспект проблеми формування наукової картини світу в Україні, аналізував ці питання в контексті викладання дисциплін гуманітарного та природничого циклів [4]. Зазначене орієнтує на звернення до вітчизняного досвіду та розгдяд стану проблеми у другій половині XX століття. Період характеризувався в Українській республіці як періодичними спробами потужного реформування освіти, так і низкою менш масштабних нововведень. Всі вони різною мірою впливали на зміст освіти, викликали різнорівневі зміни, що обов'язково відбивалися на формуванні змісту книг для шкільного навчання.

Зазвичай у підручник закладається певний спосіб організації засвоєння інформації, необхідної для утворення цілісних світоглядних уявлень у здобувачів освіти [2]. Тож зі змінами підходів до характеру викладання трансформувадися і механізми розроблення підручників як засобів навчання учнів.

Учені стверджують, що вперше об'єктом наукового дослідження підручник став у 50-х роках ХХ стодіття. Тоді у монографіях Н. О. Менчинської та Є. Й. Перовського було обгрунтовано методичну побудову підручників, акцентовано на важдивості врахування психолого-педагогічних вимог до їх розроблення. За твердженням авторів, у 50-х роках минулого століття підручник уже вважався не тільки джерелом достовірної інформації для вчителя; його першорядними функціями тоді ставали закріплення і контродь [3]. Зміст формувався так, щоб надати школярам мождивість повторити, закріпити матеріад, виконати домашне завдання, дати відповіді на репродуктивні питання.

У тогочасних дослідженнях Д.Д.Зуєв трактував теорію шкільного підручника як «систему гдибокого наукового обгрунтування головних його параметрів для вивчення закономірностей створення навчальної дітератури, що допомагала б їі розвитку» [1, с. 250]. Результатами розвитку теорії підручника стало зростання уваги до його змісту, відбиття фундаменталізації освіти в навчальній книзі більш високого рівня, оновлення вимог до їі розроблення і створення.

Початком комплексного дослідження навчальної книги в УРСР Я.П. Кодлюк називає 60-і роки XX століття. Посилення уваги до цієї проблеми науковець пов'язує з підготовкою шкільної реформи, результатом якої став перехід до загальної обов'язкової спочатку семирічної, а потім восьмирічної освіти [3, с. 9]. Тоді реформування освітньої галузі супроводжувалося значним розширенням шкільної мережі. Розроблення нового змісту освіти зумовдювало необхідність упровадження нових навчальних планів, програм. Усе це мало відображатися в оновлених підручниках, які останнім часом тільки передруковувалися без змін і доповнень.

На перевидання навчальної книги, як і на будь-які нововведення та альтернативні рішення, консервативне Міністерство освіти зазвичай реагувало негативно. Однак, починаючи $з$ 1963-1964 н.р., після відновлення 10-річного терміну шкільного навчання, забезпечення освітнього закладу якісними підручниками стало одним із першочергових внутрішньогалузевих завдань [5].

За висновками В. В. Кузьменка, до підручника з природничих дисциплін (фізика, хімія, біологія, географія тощо) висувадися такі вимоги: «Підручник повинен містити глибокий, чіткий і ясний виклад основ природничих наук, формувати в учнів науковоматеріалістичний світогляд) [4, с. 199]. Проте традиційний для вітчизняного реформування, авральний спосіб упровадження освітніх нововведень призвів до невчасного розроблення i забезпечення шкіл новими навчальними книгами. Тож школярі були змушені деякий час навчатися за старими, попередньо розробленими підручниками.

В. В. Кузьменко зазначає: «Керівництво країни розуміло, що наявність якісної навчальної літератури - запорука успішної роботи школи, а тому приймало відповідні

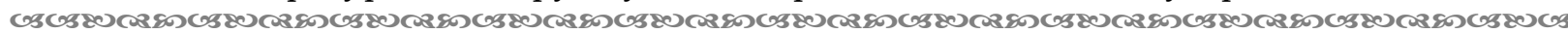
205 
заходи. Так, у постанові ЦК КПРС і Кабінету Міністрів СРСР від 10 листопада 1966 року «Про дальше удосконалення роботи середньої загальноосвітньої школи» вимагалося від Міністерств освіти СРСР і союзних республік прийняття заходів для створення високоякісних шкільних підручників і залучення до їх написання провідних учених та досвідчених учителів. Після виходу цієї постанови почали створюватися кращі умови для розробки і видання нових стабільних підручників. Однак проблеми з виданням і забезпеченням підручниками шкіл залишалися ще довгий час» [4, с. 298].

Упродовж 60-х - 70-х років XX стодіття зміст підручників 3 предметів природничого циклу поступово змінювався. Такі зміни дослідники пов'язують з переходом школи на новий зміст і тривалість навчання; необхідністю забезпечення підручниками процесу підготовки реформи шкоди; поодинокими спробами розроблення альтернативних навчальних книг тощо [4], хоча офіційною педагогікою не дуже схвалювалися прояви варіативності.

Студіювання науково-педагогічної літератури підтвердило наявність у 70-80-х роках минулого століття (на тлі стагнації у загальнодержавному розвитку) існування таких явищ у процесі підручникотворення як безальтернативність та статичність у питаннях оновлення змісту підручників для шкіл тощо. Школа, як і все суспільство, потребувала розгортання динамічних змін в освіті. Ії зміст, з огляду на науковотехнічний процес, численні наукові відкриття, застарівав дуже швидко, його оновлення потребувало активізації підручникотворчого процесу, збагачення методичного апарату, зростання уваги до врахування способів активізації пізнавальної творчої діяльності дітей та учнівської молоді.

Подібна ситуація склалася тоді й щодо розроблення шкільних підручників природничих дисциплін. Як і всі інші, тривалий час вони перевидавалися майже без змін. Однак суперечність, що виникала між рівнем і обсягом знань, відображених уматеріалах підручників, та розвитком природничо-наукової картини світу мала вирішуватися, адже така ситуація вже не задовольняла ні викладача й учня, ані освіту й суспільство.

Потребу у розробленні та забезпеченні школи якісно новими підручниками 3 новим змістовим наповненням та оновленими теоретико-методичними підходами почали активно задоводьняти в другій половині 80-х років XX століття у результаті проголошення чергової реформи загальноосвітньої школи (1984р.). Це була остання спроба радянської педагогічної теорії і практики покращити тогочасну освітню ситуацію.

Фахівцями з природничих дисциплін було переглянуто структуру підручника, його мову і стиль, роль і місце серед інших засобів навчання; критерії до його аналізу та оцінювання; специфіку конструювання підручників математики, фізики, хімії, географії, біології тощо; особливості наповнення для модернізованої шкоди, методичні рекомендації для розроблення i користування новими підручниками. Тепер здійснювалося системне дослідження теорії і практики підручникотворення, результатами якого мали стати реалізація провідних принципів: науковості, цілісності, природовідповідності, самостійності та ін.

Визнаючи певну нерівномірність у розвитку теорії шкільного підручника, що простежувалася на цьому етапі, вітчизняні науковці (Л. Д. Березівська, Я. П. Кодлюк, В. В. Кузьменко та ін.) назвали підручникотворення одним із центальних напрямів розбудови національної школи незалежної України [3, с. 65]. Характерними ознаками підручникотворення 90-х років минулого століття стали варіативність, розвивальне спрямування, розширення типології шкільних підручників, суттєве зміщення змістових акцентів з ідеологічних прокомуністичних на загальнонаціональні, українознавчі. Теоретичним же підгрунтям розроблення шкільних підручників на всіх етапах розвитку вітчизняної освіти залишалися ті принципи і підходи, що визначадися як потужними 
реформами, так i перманентними змінами, детермінованими незначними нововведеннями.

У період розбудови національної освіти активно розглядалися проблеми оптимізації підручникотворення, вдосконалення його якості, відповідності сучасним вимогам, надбанням психолого-педагогічної теорії і практики.

Ідею створення єдиного підручника, присвяченого цілісному висвітлено всього, що пов'язано 3 живою природою, наприкінці XX століття запропонувала А. В. Степанюк. У своїх наукових працях, присвячених актуальним проблемам формування в учнів цілісних знань про живу природу, науковець запропонувала своє бачення такого процесу. Надаючи великого значення фундаменталізації та генералізації змісту природничої освіти, вчена пропонувала формувати природничо-наукові уявлення в школярів засобами добору та структурування змісту інтегрованого навчального матеріалу; через упровадження в зміст шкільної освіти єдиного навчадьного предмета про живу природу. Ця структурована за блоками, взаємопов'язана інформація для засвоєння природничих понять мала відбиватися у якісному підручнику [6]. Нині ця ідея набула популярності й починає успішно втілюватися в реформуванні національної освіти (Концепція Нової української школи), хоча і залишається дискусійною серед певного кола теоретиків та практиків.

Нині на необхідності взаємодії науковців під час створення підручників для закладів освіти наголошуе переважна більшість дослідників, учених, практиків. Вони підкреслюють важливість співпраці авторів підручників 3 метою дотримання наступності, цілісного викладу матеріалу, уникнення повторів у книгах одного (природничого або гуманітарного) циклу та застосування можливостей інтеграції змісту освіти для реалізації закладених у навчальні програми компетенцій.

Висновки. Отже, вивчення наукових праць учених, що досліджували ці питання (А. Д. Березівська, Я. П. Кодлюк, В. В. Кузьменко та ін.), дає змогу не тільки простежити динаміку розвитку вітчизняного підручникотворення, а й визначати залежність трансформації змісту шкільної навчальної книги від реформаційних змін. Констатуємо також поступові зміни у призначенні підручника: від застосування його як засобу репродуктивного відтворення інформації і контролю через визнання його інструментом для цілеспрямованого навчального i виховного впливу на здобувача освіти, до формування загадьної культури і життєвої компетентності кожного представника молодого покоління.

Таким чином, продуктивний історичний досвід розвитку теорії та практики навчальної книги з вивчення природничих дисциплін у другій половині XX століття може бути корисним для підручникотворення Нової української школи.

У подальших наукових розвідках потребують додаткового дослідження проблеми розроблення критеріїв відбору матеріалу у зміст підручників (з урахуванням специфіки змісту природничих дисциплін; вікових особливостей учнів; системи ціннісних орієнтирів, що е пріоритетними у суспільстві); а також вивчення зарубіжного досвіду підручникотворення з природничих дисциплін.

\section{Список використаних джерел:}

1. Зуев Д.Д. Научно-организационные проблемы развития теории школьного учебника. Проблемы школьного учебника. Москва: Просвещение, 1978. Вып. 6. С. 250.

2. Кодлюк Я. Теорія шкільного підручника як психолого-педагогічна проблема. Наукові записки Тернопільського державного педагогічного університету (Серія: Педагогіка). 2000. № 8. С. 3-7.

3. Коддюк Я. П. Теорія і практика підручникотворення в початковій освіті: підручник для магістрантів та студентів педагогічних факультетів. Київ: Інформаційно-аналітична агенція «Наш час», 2006. 368 с.

4. Кузьменко В. В. Формування наукової картини світу учнів: від витоків до сьогодення: монографія. Херсон: РІПО, 2007. 600 с. 
5. Про стан підготовки та видання підручників і навчальних посібників для загальноосвітніх шкіл Української РСР. Збірник наказів та інструкцій Міністерства освіти Української РСР. 1962. № 12. C. 4-8.

6. Степанюк А. В. Методологічні та теоретичні основи формування цілісності знань школярів про живу природу: дис. ... д-ра пед. наук: 13.00.01. Тернопіль, 1999. 474 с.

\section{References:}

1. Zuev, D. D. (1978). Nauchno-organizatcionnye problemy razvitiia teorii shkolnogo uchebnika [Scientific and organizational problems of the development of the theory of a school textbook]. In Problemy shkolnogo uchebnika [School textbook problems] (p. 250). Moskva: Prosveshchenie [in Russian].

2. Kodliuk, Ya. (2000). Teoriia shkilnoho pidruchnyka yak psykholoho-pedahohichna problema [School textbook theory as a psychological and pedagogical problem]. Naukovi zapysky Ternopilskoho derzhavnoho pedahohichnoho universytetu (Seriia: Pedahohika), 8, 3-7 [in Ukrainian].

3. Kodliuk, Ya. P. (2006). Teoriia i praktyka pidruchnykotvorennia $v$ pochatkovii osviti [Theory and practice of textbook creation in primary education]. Kyiv: Informatsiino-analitychna ahentsiia «Nash chas» [in Ukrainian].

4. Kuzmenko, V. V. (2007). Formuvannia naukovoi kartyny svitu uchniv: vid vytokiv do sohodennia [Formation of a scientific picture of the world of students: from the origins to the present]. Kherson: RIPO [in Ukrainian].

5. Pro stan pidhotovky ta vydannia pidruchnykiv $i$ navchalnykh posibnykiv dlia zahalnoosvitnikh shkil Ukrainskoi RSR [On the state of preparation and publication of textbooks and manuals for secondary schools of the Ukrainian SSR]. (1962). Zbirnyk nakaziv ta instruktsii Ministerstva osvity Ukrainskoi RSR, pp. 4-8 [in Ukrainian].

6. Stepaniuk, A. V. (1999). Metodolohichni ta teoretychni osnovy formuvannia tsilisnosti znan shkoliariv pro zhyou pryrodu [Methodological and theoretical bases of formation of pupils' knowledge integrity about the living nature]. (Doctor's thesis). Ternopil [in Ukrainian].

Prymakova $V$. V., orcid.org/0000-0002-8914-6748

\section{THE INFLUENCE OF EDUCATIONAL REFORMS ON THE DEVELOPMENT OF CREATION OF SCHOOL TEXTBOOK ON NATURAL DISCIPLINES IN UKRAINE IN THE SECOND HALF OF THE XX CENTURY}

The article is devoted to the consideration of the historical and pedagogical aspect of the problem of textbook creation, in particular the influence of educational reforms on its development in Ukraine in the second half of the twentieth century. The author substantiates the urgency of the problem, clarifies the content of key concepts "textbook creation", "textbook theory", analyzes the advantages and difficulties, strengths and weaknesses in creating a school textbook on natural sciences in education at that time, traced the vector and dynamics of changes in this process within outlined chronological boundaries.

Studying of scientific works on the history of pedagogy have made it possible to find out how scientific and technological progress, the ruling power at different stages of development of society, socio-political and socio-economic conditions have caused problems and some difficulties in this direction of activity of educational branch.

As the requirements for the school textbook have always been high, the process of its creation required special approaches, improving the quality of its development and production, while modernizing the structure, updating the content. An attempt is made to trace the nature of such changes in the period from the early 1950s to the beginning of the next.

Modern requirements for the development of school textbooks have become much more complicated. At the same time, the classical canons, prescribed in the days of Y. A. Comenius, remain relevant today. Accordingly, based on a retrospective analysis of processes in this period, the mechanisms of textbook creation, difficulties and nature of changes in the algorithm of development, selection, implementation of the school book, taking into account its specifics for the study of natural sciences are defined. 
Based on the analysis of scientific and pedagogical literature revealed the main achievements in solving problems of creating a school textbook for the study of natural sciences, identified opportunities for extrapolation of constructive experience of the past in modern theory and practice of education, which periodically undergoes significant transformations.

Key words: educational reform; textbook creation; textbook theory; natural education; subjects of the natural cycle.

Дата надходження статті: 11.12.2020 p.

Рецензент: доктор педагогічних наук Чумак $\Lambda$. В.

\author{
У,ДК 37.011+37.013.3 \\ DOI https://doi.org/10.37915/pa.vi47.170
}

Стражнікова I. B. orcid.org/0000-0001-5921-6197

\title{
ІСТОРІОГРАФІЧНИЙ АСПЕКТ ПІДГОТОВКИ ОСВІТНІХ ЕКСПЕРТІВ У ЗАКЛАДАХ ВИЩОЇ ОСВІТИ
}

Сучасна ситуація в Украӥні характеризуеться стрімкими змінами політичної, економічної, соціальної та культурної сфер людської діяльності. У таких умовах саме освіта зазнае значних змін, адже покликана усвідомити нове освітне конкурентоздатне замовлення, що вимагає акценту на надання тим, хто навчається, певного обсягу знань, умінь, навичок; формування креативної особистості, що відповідально ставиться до прийнятих рішень, здатна виробити свою позицію в житті, світогляд та обстоювати обрані цінності. Тому освіта змінюватиме свій статус, має стати громадсько-державною системою - зробити людину спроможною забезпечувати особисте самодостатне життя, водночас за свою діяльність система освіти повинна відповідати і перед громадськістю, i перед державою; сучасна система освіти покликана стати відкритою та піддати себе певному нагляду й опіці з боку широкої громадськості.

у статті проаналізовано аспекти проблеми підготовки експертів з освіти в історіографічному ракурсі. Досліджено сутність поняття «експерт», описуються принципи підготовки експертів, напрями розвитку наукової експертизи у сфері освіти та компетенції, якими мають володіти експерти в галузі освіти. Охарактеризовано компетентності фахівия-експерта завдяки історіографічному аналізу досліджень українських $і$ зарубіжних науковиів. Нами доведено, щя у науковій літературі «експертиза в освіті» розглядається яксистемний аналіз проблеми, процесу чи явища у сфері освіти чи в одній із ї̈ підсистем зметою визначення стимулюючих або гальмуючих чинників, їх розвиток із наступним закріпленням або усуненням. Історіографічний аналіз дозволив висвітлити й функцій експертизи в освіті та зрушення в процесі ліцеензування закладів освіти.

У зв'язку з цุим важливим складником у реалізації освітньо-професійної програми з підготовки магістрів освітніх наук е практична підготовка, що відображено у профілі освітньо-професійної програми за спеціальністю 011 Освітні, педагогічні науки різних закладів вищьої освіти Украӥни, з урахуванням вимог до майбутнвого освітнъого експерта та його посадових обов'язків.

Ключові слова: освіта, підготовка експертів, заклад вищої освіти, принципи, історіографія, фахівецьь, освітньо-професійна програма, магістр.

Постановка проблеми. Сучасна освіта є визначальним чинником і потужним рушієм розвитку суспільства, тому перспективним вважається аналіз її проблем, їх суті

*C) Стражнікова I. B.

03 